\title{
Investigations on hepatic and intestinal drug-metabolizing cytochrome P450 enzymes in wild boar compared to domestic swine
}

\author{
Ádám Kurucz ${ }^{1} \cdot$ Kata Orbán $^{1} \cdot$ Máté Mackei $^{1} \cdot$ Hedvig Fébel $^{2} \cdot$ Zsuzsanna Neogrády $^{1} \cdot$ Gábor Mátis $^{1}$ (I)
}

Received: 28 April 2019 / Revised: 15 September 2019 / Accepted: 1 December 2019 /Published online: 19 December 2019

(C) The Author(s) 2019

\begin{abstract}
Drug-metabolizing cytochrome P450 (CYP) enzymes are especially important in wild animals as they are directly exposed to environmental pollutants and bioactive molecules of plants. Our main goal was to monitor the activity of certain CYP enzymes in wild boar compared to domestic swine, and to assess various modulatory factors of xenobiotic biotransformation in wild boar. Liver and intestinal mucosa (duodenum, jejunum, ileum, caecum) samples were collected from 49 hunted free-range wild boars and 15 wild boar fetuses; domestic pig samples $(n=40)$ were gained from a slaughter house. Specific activity of CYP1A2, CYP2C9, and CYP3A4 enzymes was assessed by luminometric assays. The activity of hepatic CYP1A2 and CYP3A4 enzymes was significantly higher in wild boars than in domestic pigs, while CYP2C9-mediated hepatic metabolism was significantly less intense in wild boars than in pigs. Certain modulatory factors (sex, sexual maturation, and season) were also confirmed in wild boars. The activity of all investigated intestinal CYP enzymes remained under detection level in each gut section in both species. Hepatic CYP2C9 and CYP3A4 enzymes were measurable in wild boar fetuses, but their activity was remarkably lower than in adults. The described interspecies differences might be explained with the altered exposure of wild and domesticated animals to specific CYP modulators. As CYP enzymes in wild boars can be highly influenced by environmental pollutants, following further studies, they may serve as ecotoxicological markers of agricultural or industrial toxicants. Investigating CYP-related drug metabolism in wildlife species can clarify some toxicokinetic interactions, thus having huge importance in the production of safe game meat.
\end{abstract}

Keywords Drug metabolism $\cdot$ Cytochrome P450 $\cdot$ Ecotoxicology $\cdot$ Comparative physiology $\cdot$ Wild boar

\section{Introduction}

The biotransformation of xenobiotics, such as that of pollutants, toxicants, and drugs, is of high importance in all animal species, especially in wild animals, being directly exposed to numerous environmental factors. Cytochrome P450 (CYP) enzymes play key role in the first phase of xenobiotic biotransformation by catalyzing mostly

Gábor Mátis

matis.gabor@univet.hu

1 Division of Biochemistry, Department of Physiology and Biochemistry, University of Veterinary Medicine, István utca 2, Budapest 1078, Hungary

2 Research Institute for Animal Breeding, Nutrition and Meat Science, National Agricultural Research and Innovation Center, Gesztenyés út 1, Herceghalom 2053, Hungary oxidative processes, primarily hydroxylations, hence enabling the subsequent conjugation with strongly polar molecules in the second phase reactions (Anzenbacher and (Anzenbacher and Anzenbacherová 2001; Kulcsár et al. 2016). The CYPs as microsomal monooxygenases can be found in the endoplasmic reticulum of various cell types, first of all in the liver, and also in the intestinal epithelium, lungs, and kidney. Among these organs, liver has the highest detoxifying capacity and thus the main role in CYP-mediated drug metabolism, but the biotransformation of orally ingested xenobiotics already starts in the small intestines (Herbert et al. 1992; 1996; Wu et al. 1995). As a primary metabolic barrier, intestinal CYP enzymes provide the first line of detoxification, and form a complex system together with the major drug-metabolizing activity of the liver (Lin et al. 1999; Thummel et al. 1996). Beside xenobiotic biotransformation, CYPs are also highly involved in steroid metabolism, e.g., in the synthesis of steroid hormones and bile acids, acting on 
a great variety of endogenous substrates as well (Anzenbacher and Anzenbacherová 2001).

CYP enzymes can be classified into 14 families and to further subfamilies, which are highly similar in different animal species. In contrast to their mostly species-independent function and substrate preference, the expression and activity of certain CYPs, as well inducible enzymes, can be completely different in various species and might be greatly influenced by a huge variety of factors, such as by xenobiotics, nutritional factors, sex, and age (Fink-Gremmels 2008; Mátis et al. 2013).

Investigations regarding CYP enzymes in wild animals, first of all in hunted species, can be of high interest because of their increased exposure to environmental influencing factors, especially to agricultural or industrial pollutants, bioactive molecules of plants, and the applied feed additives. Since the activity of drug-metabolizing CYPs is supposed to greatly correlate with the presence of potential inducers or inhibitors, CYP activities in wild animals may reflect the xenobiotic exposures in the appropriate area, which makes their study highly relevant from ecotoxicological point of view as well (Kurucz et al. 2018). In most cases, game meat is used for human consumption; therefore, investigating xenobiotic biotransformation in the majority of hunted species should be also considered as a food safety issue. Further, comparing the function of CYP enzymes in different wild animal species and their domestic counterparts is also interesting as a comparative physiological and toxicological approach, and such studies can also facilitate to explore potential species-specific "feed-drug" and "drug-drug" interactions (Kurucz et al. 2018).

However, only limited data are available concerning hepatic CYP enzymes in wild animals. Machala et al. (2003) investigated the activity of certain hepatic CYP subfamilies in red deer (Cervus elaphus), fallow deer (Dama dama), roe deer (Capreolus capreolus), and mouflon (Ovis musimon). In most cases, wild ruminants showed significantly higher hepatic CYP enzyme activities than domestic cattle (Bos taurus), indicating the intense metabolism of xenobiotics and steroids. The CYP1A subfamily was the most active in fallow deer and roe deer, CYP2B showed the highest activity in fallow deer, while, in contrast, CYP2C, CYP2D, and CYP2E activities were especially increased in mouflon (Machala et al. 2003). It was also described that the well inducible and inhibitable etoxiresorufin O-dealkylase activity of hepatic CYP1A was significantly greater in sika deer (Cervus hortulorum yesoensis) than that of the constitutive metoxyresorufin $\mathrm{O}$ dealkylase, but these enzyme activities did not differ from each other in cattle, reflecting the presence of environmental inducers in wild species (Darwish et al. 2010). The oxidative metabolism of albendazole (mainly catalyzed by CYP3A and CYP2C subfamilies and flavin monooxygenases) was significantly less intensive in wild cervids compared to cattle; however, albendazole had similar pharmacokinetic properties in wild boar (Sus scrofa) and domestic swine (Sus scrofa domestica) (Velík et al. 2005). Regarding carnivores, Ishizuka et al. (2006) found that mink (Mustela vison) had remarkably lower CYP2D activity than silver fox (Vulpes vulpes) or dog (Canis lupus familiaris). Beyond their baseline activities, the inducibility of CYP enzymes can also highly differ in various species. For instance, CYP1A and CYP3A were greatly induced by ivermectin in the liver of mouflon, but with only a significantly lower extent in fallow deer (Skálová et al. 2001).

Concerning the intestinal drug metabolism, most available data are derived from human or rodent studies (Paine et al. 1996; Thummel et al. 1996; Wu et al. 1995). The baseline activity and the possible nutritional modulation of CYP enzymes in the duodenal mucosa in chickens were recently described by Kulcsár et al. (2017), while other studies provided data regarding the expression of certain CYP enzymes in the gut of domestic swine (Nielsen et al. 2017; Puccinelli et al. 2011). However, no information can be found until now about the intestinal xenobiotic biotransformation in game species.

According to the mentioned literature sources, it can be suggested that great differences may exist in the CYPrelated drug metabolism in various wild game species, especially compared to domestic animals. Further investigations on xenobiotic biotransformation in wild species can be of special interest from basic science, toxicology, and food safety approach. As wild species are directly exposed to environmental influencing factors (such as pollutants or bioactive compounds of plants), highly inducible CYP enzymes can possibly serve as ecotoxicological markers. Since there is nearly no evidence about the hepatic xenobiotic metabolism in wild boar, and absolutely no data regarding intestinal CYPs in any wild species, the main aim of the present study was to measure the activity of several CYP enzymes in the liver and intestines of wild boar compared to domestic pig, and to study the effects of several factors on drug metabolism in wild boar.

\section{Materials and methods}

\section{Sample collection from wild boar}

Tissue samples for assessing CYP enzyme activities were collected from free-range wild boars on individual and driven hunts in two closely located hunting areas of Western Hungary (Sopronkövesd and Sárvár) with the permission of the appropriate hunting associations (Széchenyi István and Vadkert Hunting Association, respectively). As CYP enzymes can be influenced by numerous environmental and genetic factors, wild boars of both sexes, several ages, and from all seasons were included in the study. Altogether, 49 wild boars were sampled; furthermore, 15 wild boar fetuses (only for liver sampling; 5 fetuses originated from the first phase 
[approx. weeks 1-6], 4 from the second phase [approx. weeks 7-12], and 6 from the last phase [approx. weeks 13-17] of pregnancy) were involved in the research. The most important data of sampled wild boars (excluding fetuses) are indicated in Table 1 .

Immediately after evisceration on the spot (Fig. 1a), samples were taken from the caudate lobe of the liver (Fig. 1b), and from the mucosa of the duodenum, jejunum, ileum, and cecum of the boars (Fig. 1c, d). In case of intestinal samplings, the appropriate intestinal section was excised and longitudinally opened on the mesenteric side, flushed with chilled physiological saline solution, and the mucosa was gently scraped with a microscope slide (Fig. 1c, d). All tissue samples were shock-frozen in dry ice and were subsequently stored at $-80^{\circ} \mathrm{C}$ until further processing.

\section{Sample collection from domestic swine}

For comparative studies, liver and intestinal samples were gained from domestic pigs on the same way as from wild boars. Tissue samples were taken in a slaughter house (Keselyüs-Hús Kft., Szekszárd) from 40 pigs (24 females and 16 castrated males) of the Hungarian Large White breed weighing approx. $110 \mathrm{~kg}$, originated from a commercial pig farm in Western Hungary (Backó Kft., Pötréte). Pigs were previously fed by a standard diet for swine fattening, being free of any antibiotics or further drugs and containing only vitamins, minerals, xylanase $(400,000$ BXU/kg diet), and phytase (2000 FTU/kg diet) as supplements. Similarly to those of wild boars, all samples from domestic pigs were immediately shock-frozen in dry ice, and were stored at $-80^{\circ} \mathrm{C}$ until analyses.

\section{Laboratory analyses}

Tissue samples were thawed on ice and were homogenized in $5 \mathrm{ml}$ of $50 \mathrm{mM}$ phosphate buffer (containing $250 \mathrm{mM}$ sucrose, 1 mM EDTA and 20\% glycerol, pH 7.4, supplemented with $1 \%$ of Halt Protease Inhibitor Cocktail [Thermo Fisher Scientific, Waltham, Massachusetts, USA]). The microsome-enriched postmitochondrial supernatant was isolated by a two-step differential centrifugation according to Kulcsár et al. (2017). Briefly, the homogenate was firstly centrifuged at $600 \mathrm{~g}$ on $4{ }^{\circ} \mathrm{C}$ for $1 \mathrm{~min}$, then the supernatant was centrifuged again at $9000 \mathrm{~g}$ on $4{ }^{\circ} \mathrm{C}$ for $30 \mathrm{~min}$, and thereafter the supernatant was used for further measurements.

To ensure equal protein loading for enzyme assays, total protein concentration of postmitochondrial supernatants was measured by the Pierce ${ }^{\mathrm{TM}}$ BCA Protein Assay Kit (Thermo Fisher Scientific, Waltham, Massachusetts, USA) according to the manufacturer's instructions; the absorbance was detected by a Multiskan GO 3.2 reader at the wave length of $562 \mathrm{~nm}$. As the parenchymal organs of hunted wild boars can be less exsanguinated than those of slaughtered pigs, the hemoglobin concentration of liver samples was determined by adding $180 \mu \mathrm{l}$ of $0.1 \%$
Table 1 Data of the hunted wild boars included in the study (excluding fetuses)

\begin{tabular}{|c|c|c|c|c|}
\hline Identification No & Hunting area & Season & Age & Sex \\
\hline 1 & Sárvár & Spring & $\sim 1$ year & Female \\
\hline 2 & Sárvár & Spring & $\sim 1$ year & Female \\
\hline 3 & Sopronkövesd & Spring & $\sim 1.5$ years & Female \\
\hline 4 & Sárvár & Spring & $\sim 1$ year & Female \\
\hline 5 & Sárvár & Summer & $\sim 1$ year & Female \\
\hline 6 & Sopronkövesd & Summer & $\sim 1$ year & Male \\
\hline 7 & Sopronkövesd & Summer & $\sim 1$ year & Male \\
\hline 8 & Sopronkövesd & Summer & $\sim 3$ months & Male \\
\hline 9 & Sárvár & Summer & $\sim 4$ months & Female \\
\hline 10 & Sopronkövesd & Summer & $\sim 3$ months & Female \\
\hline 11 & Sopronkövesd & Summer & $\sim 5$ years & Male \\
\hline 12 & Sárvár & Summer & $\sim 1$ year & Female \\
\hline 13 & Sopronkövesd & Summer & $\sim 1$ year & Female \\
\hline 14 & Sopronkövesd & Summer & $\sim 3$ years & Male \\
\hline 15 & Sárvár & Summer & $\sim 1$ year & Male \\
\hline 16 & Sopronkövesd & Summer & $\sim 4-5$ years & Female \\
\hline 17 & Sopronkövesd & Summer & $\sim 3$ years & Female \\
\hline 18 & Sárvár & Summer & $\sim 1$ year & Male \\
\hline 19 & Sárvár & Summer & $\sim 1$ year & Female \\
\hline 20 & Sopronkövesd & Summer & $\sim 4$ months & Female \\
\hline 21 & Sárvár & Autumn & $\sim 1$ year & Male \\
\hline 22 & Sárvár & Autumn & $\sim 2$ years & Female \\
\hline 23 & Sárvár & Autumn & $\sim 6$ months & Male \\
\hline 24 & Sárvár & Autumn & $\sim 7$ months & Male \\
\hline 25 & Sárvár & Autumn & $\sim 1.5$ years & Male \\
\hline 26 & Sopronkövesd & Autumn & $\sim 4$ years & Male \\
\hline 27 & Sopronkövesd & Autumn & $\sim 2$ years & Male \\
\hline 28 & Sárvár & Autumn & $\sim 2$ years & Female \\
\hline 29 & Sopronkövesd & Winter & $\sim 6$ months & Female \\
\hline 30 & Sopronkövesd & Winter & $\sim 2$ years & Female \\
\hline 31 & Sopronkövesd & Winter & $\sim 2$ years & Female \\
\hline 32 & Sopronkövesd & Winter & $\sim 2$ years & Male \\
\hline 33 & Sopronkövesd & Winter & $\sim 2$ years & Female \\
\hline 34 & Sopronkövesd & Winter & $\sim 4-5$ years & Female \\
\hline 35 & Sopronkövesd & Winter & $\sim 2$ years & Female \\
\hline 36 & Sopronkövesd & Winter & $\sim 7$ months & Female \\
\hline 37 & Sopronkövesd & Winter & $\sim 2$ years & Female \\
\hline 38 & Sopronkövesd & Winter & $\sim 1$ year & Male \\
\hline 39 & Sopronkövesd & Winter & $\sim 7$ months & Female \\
\hline 40 & Sopronkövesd & Winter & $\sim 7$ months & Male \\
\hline 41 & Sopronkövesd & Winter & $\sim 7$ months & Female \\
\hline 42 & Sopronkövesd & Winter & $\sim 7$ months & Male \\
\hline 43 & Sopronkövesd & Winter & $\sim 8$ months & Female \\
\hline 44 & Sopronkövesd & Winter & $\sim 2.5$ years & Male \\
\hline 45 & Sárvár & Spring & $\sim 1$ year & Female \\
\hline 46 & Sárvár & Spring & $\sim 1$ year & Female \\
\hline 47 & Sárvár & Spring & $\sim 1$ year & Female \\
\hline 48 & Sárvár & Summer & $\sim 4-5$ years & Female \\
\hline 49 & Sopronkövesd & Summer & $\sim 1$ year & Female \\
\hline
\end{tabular}


Fig. 1 The main steps of samplings from wild boar for monitoring drug-metabolizing CYP enzymes. (a) Preparations for sampling directly following the evisceration. (b) Tissue sampling from the caudate lobe of the liver. (c) The jejunum is getting longitudinally opened and flushed in chilled physiological saline solution. (d) The intestinal mucosa is gently scraped by a microscope slide. (Photos taken by Csaba Nagy)
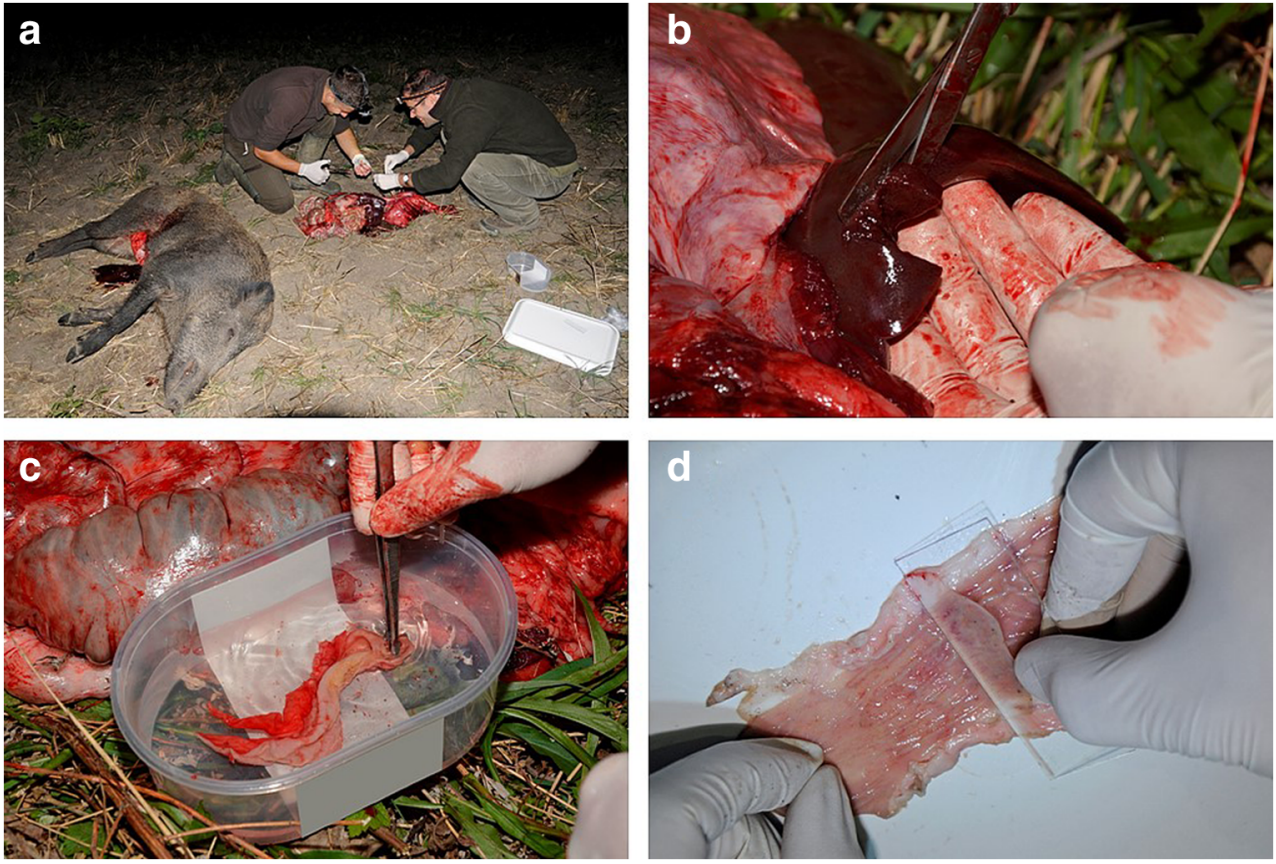

ammoniac reagent (Molar Chemicals, Budapest, Hungary) to $20 \mu \mathrm{l}$ of each sample. After $5 \mathrm{~min}$ incubation time at room temperature, samples were scanned by the same type reader at $540 \mathrm{~nm}$ wave length.

The activity of CYP1A2, CYP2C9, and CYP3A4 enzymes was assessed by luminometric method, applying specific P450Glo ${ }^{\mathrm{TM}}$ assay kits (Promega, Madison, Wisconsin, USA). All measures were carried out according to the manufacturer's instructions, the luminescence was detected by a Victor X2 Multilabel Plate Reader. Calculated hepatic CYP enzyme activities were standardized to hemoglobin-free protein concentrations, those of intestinal CYPs to total protein levels.

\section{Statistics}

Data were statistically analyzed with the R 3.2.2 software by using multi-way ANOVA and post hoc tests for pairwise comparisons. Differences between groups were considered as statistically significant when $\mathrm{P}<0.05$. In the "Results" section, $\mathrm{P}$ values gained by post hoc tests are presented. Results are expressed as mean $\pm \mathrm{SEM}$.

\section{Results}

The activity of the hepatic CYP1A2 enzyme was significantly ( $P$ $<0.01$ ) and remarkably, approx. 4 times higher in wild boars than in domestic pigs (Fig. 2a). Similarly, CYP3A4 activity was found to be significantly $(\mathrm{P}<0.001)$, approx. 8 times increased in the liver of wild boars than in their domestic counterparts (Fig. 2b). In contrast, CYP2C9-mediated hepatic metabolism was significantly $(\mathrm{P}<0.001)$, approx. 50\% less intense in wild boars than in pigs (Fig. 2c). Regarding the intestinal xenobiotic biotransformation, the activity of all investigated CYP enzymes was under detection level in each intestinal section and in both species.

Concerning wild boars, the possible effects of several influencing factors were studied. According to our results, the age of the animals or the date of the hunting (as continuous variables) did not have any effect on CYP enzymes, and there were no significant differences when comparing boars sampled in the two, closely located hunting areas. However, hepatic CYP1A2 activity was significantly $(\mathrm{P}<0.05)$, approx. 3 times higher in female than in male boars (Fig. 3a), and the activity of CYP3A4 was highly (approx. 5 times), significantly $(\mathrm{P}<0.05)$ increased in sexually matured sows when compared to juvenile ones (Fig. 3c). (The age of sexual maturity was considered as 1 year in females and as 2 years in males according to Faragó 2002.) Further, to assess some nutritionrelated alterations in drug metabolism, we aimed to compare the summer (from May to September) and winter seasons (from November to February) referring to periods with optimal and poor nutrient availability. The CYP1A2 activity was significantly $(\mathrm{P}<0.05)$, more than 2 times increased in the liver of wild boars in the summer months than in winter (Fig. 3b).

In wild boar fetuses, the activity of hepatic CYP2C9 was measurable in all phases of pregnancy, however, with strongly lowered activity than in adults, while CYP3A4 activity was detected only in the liver of fetuses from the first phase of pregnancy (Fig. 4a). The sexual dimorphism of fetuses was already detectable in the third phase of pregnancy, when 
a

CYP1A2 activity

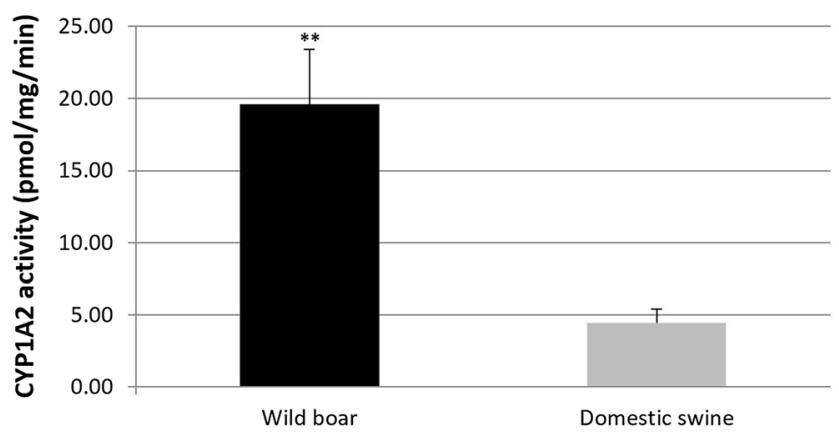

b

CYP3A4 activity

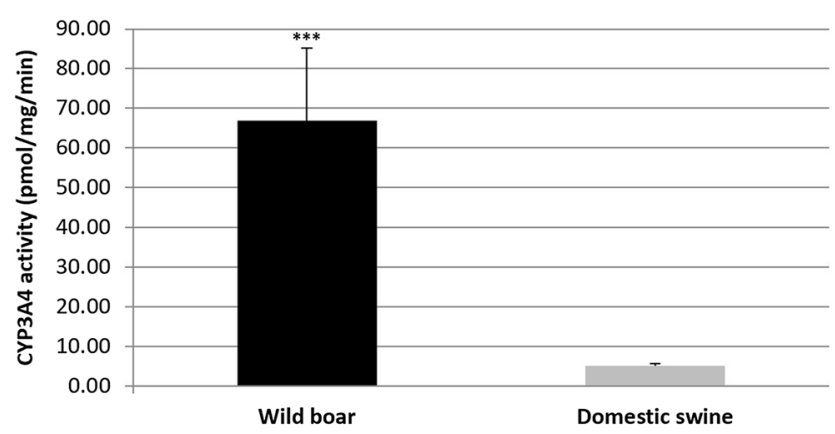

C

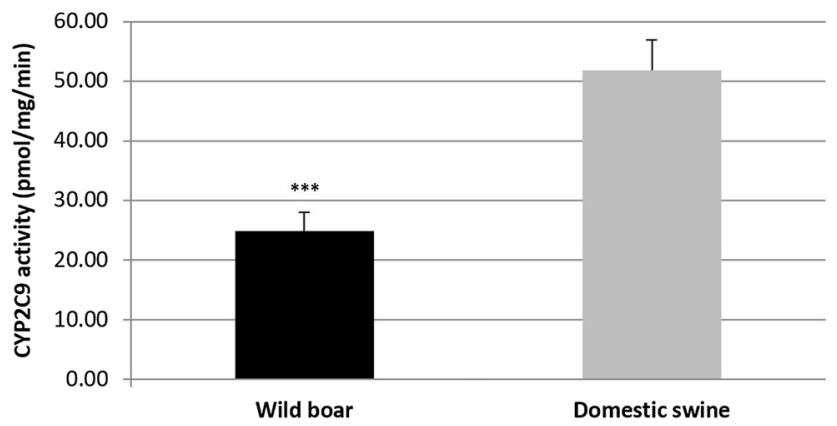

Fig. 2 The activity of hepatic (a) CYP1A2, (b) CYP3A4, and (c) CYP2C9 enzymes in the liver of wild boar and domestic swine. Results are expressed in pmol metabolized substrate per mg protein per min, as mean \pm SEM. Significant differences $* * \mathrm{P}<0.01, * * * \mathrm{P}<0.001$

females showed significantly $(\mathrm{P}<0.001)$ higher CYP2C9 enzyme activities than males (Fig. 4b).

In the case of domestic pigs, the slaughtered group of animals was homogenous and derived from the same farm; thus, the effects of age, nutrition, or sexual maturity could not be investigated. Enzyme activities of females and males (castrated) were compared, but no significant difference could be found between the two sexes.

\section{Discussion}

The activity of CYP enzymes can be highly affected by several environmental, nutritional, and genetic factors (Fink- a

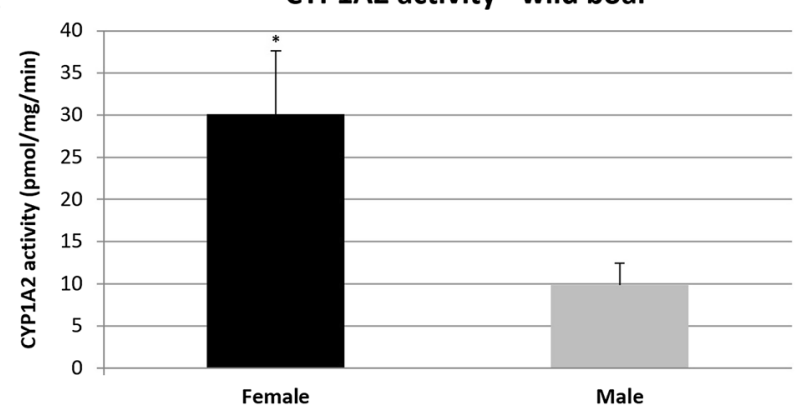

b

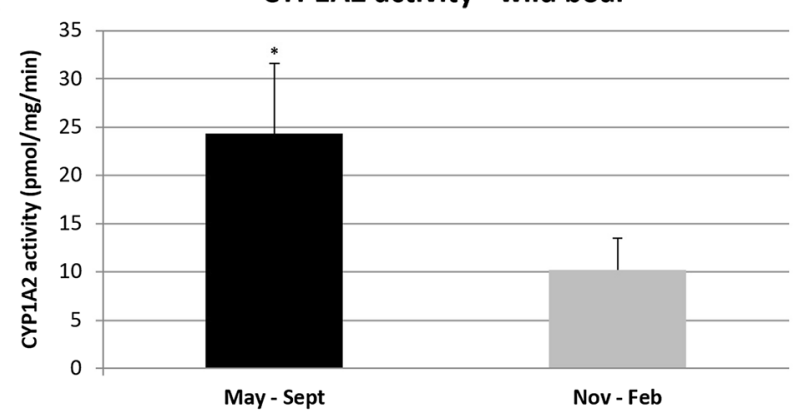

C

CYP3A4 activity - wild boar

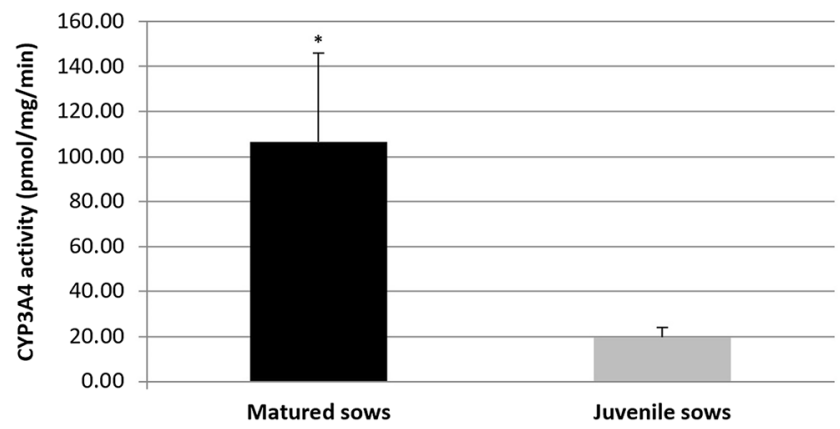

Fig. 3 Effects of different factors on hepatic CYP enzymes in wild boars. The activity of hepatic CYP1A2 in (a) females and males, (b) in the summer and winter season, and that of (c) hepatic CYP3A4 in matured and juvenile sows. Results are expressed in pmol metabolized substrate per $\mathrm{mg}$ protein per min, as mean \pm SEM. Significant differences $* \mathrm{P}<0.05$

Gremmels 2008; Mátis et al. 2013). Wild animals are directly exposed to xenobiotics originated from the agriculture or the industry, such as to pesticides and other pollutants and toxicants, and also to natural CYP modulators from the consumed plants. In intensive animal farming, feed additives provide the major possible effectors of CYP-driven drug metabolism. In our case, domestic pigs received a diet free of drugs, only vitamins and minerals were provided in standard dosage, and xylanase and phytase enzymes were used to improve nutrient digestibility.

As reflected by our results, hepatic CYP activities strongly differ in wild boar and domestic swine. The activity of CYP1A2 and CYP3A4 was greatly increased in wild boars when compared to domestic pigs, which may indicate the direct exposure of boars to environmental CYP inducers. For instance, 
Fig. 4 The activity of CYP enzymes in the liver of wild boar fetuses. The activity of (a) hepatic CYP1A2, CYP2C9, and

CYP3A4 in fetuses from various phases of pregnancy, and (b) that of hepatic CYP2C9 in female and male fetuses from the last phase (approx. weeks 13-17) of pregnancy. Results are expressed in pmol metabolized substrate per mg protein per min, as mean \pm SEM. Significant difference $* * * \mathrm{P}<0.001$
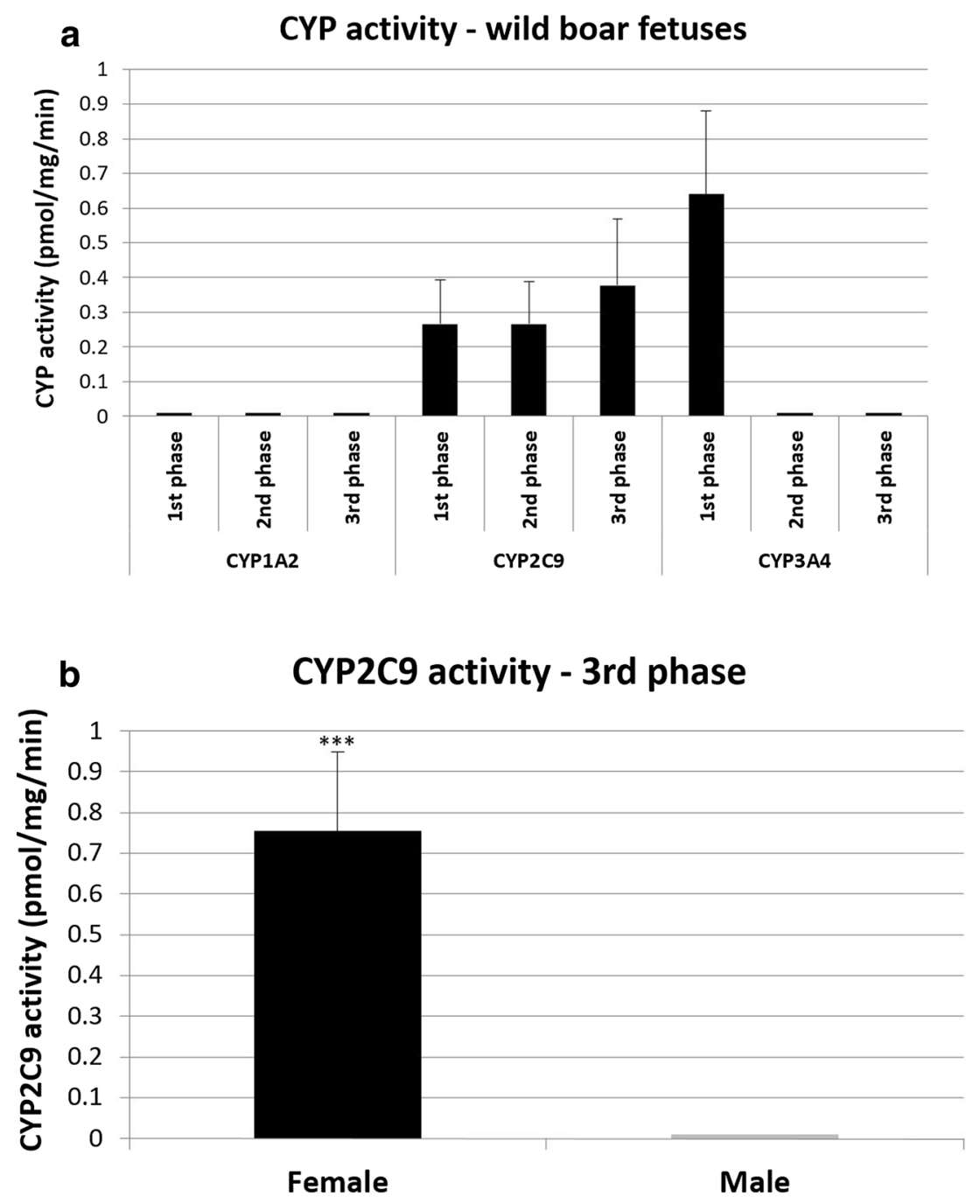

organophosphates (such as chlorpyrifos, phenamifos, fosethyl, fosmet, or fostiazate) as widely used pesticides are mainly metabolized by CYP1A2 and CYP3A4 to their especially toxic oxone forms (Buratti et al. 2005; Kaur et al. 2017), possibly contributing to the induced activity of these enzymes in wild boars. Furthermore, polycyclic aromatic hydrocarbons as industrial pollutants are potent inducers of CYP1A1 and CYP1A2 enzymes, presumably triggering enzyme induction in wild boars (Skupinska et al. 2009). Besides agricultural or industrial pollutants, natural bioactive compounds of wild or cultivated plants that are possibly accessible for wild boars can also contribute to the alterations of CYP enzyme activities (Table 2). For instance, both CYP1A2 and CYP3A4 can be induced by diallyl disulfide and sulfide, and widely presented flavonoids, such as apigenin or quercetin can elicit stimulatory action on CYP1A2 activity (Harborne and Baxter 1993, Table 2). Despite of the others, CYP2C9 was less active in wild boars than in domestic pigs, which may be in association with either inducers in domestic pig diet or inhibitors available for wild boars. Flavonoids (such as apigenin, fisetin, kaempferol, quercetin) are strong inhibitors of
CYP2C9 and can be found in numerous plants (Si et al. 2009, Table 2); thus, it can be supposed that they may have evoked the decrease in hepatic CYP2C9 activity of wild boars. However, it should be stressed that various other environmental and genetic factors may have also influenced the xenobiotic biotransformation, so further studies are needed to confirm the suggested role of the mentioned CYP modulators.

In the studied hunting areas, wild boars have access to a high variety of plants typically grown in Central Europe. Their diet is based on the available cereals (wheat, maize, rye, oat), sunflower, soy, rape, and they can also consume relevant amount of roots, bulbs, acorns, vegetables, green plant stems, berries, other fruits (such as apples or greengages), and wide range of small animals as well. Due to the good natural dietary supply, no supplemental feeding is applied by the hunting associations, just pure sodium chloride salt is provided and maize is used to bait animals for easier shooting. As wild boars are not fastidious eaters, they can consume numerous plant species containing potential CYP modulators, which are suggested to play central role in affecting drug metabolism. 
Table 2 Potential plant-derived inducers and inhibitors of the investigated CYP enzymes, accessible for wild boars in Central Europe (Harborne and Baxter 1993; Zhou et al. 2003; Si et al. 2009)

\begin{tabular}{|c|c|c|c|}
\hline $\begin{array}{l}\text { CYP } \\
\text { enzyme }\end{array}$ & $\begin{array}{l}\text { Bioactive } \\
\text { compound }\end{array}$ & Plant species & Effect \\
\hline \multirow[t]{7}{*}{ CYP1A2 } & Alpha-hederin & Hedera helix & Inhibition \\
\hline & Apigenin & $\begin{array}{l}\text { Tilia japonica, Linaria vulgaris, Cirsium arvense, Petroselium hortense, Apium graveolens, Matricaria } \\
\text { camomilla }\end{array}$ & Induction \\
\hline & $\begin{array}{l}\text { Diallyl disulfide, } \\
\text { Diallyl sulfide }\end{array}$ & Allium sativum & Induction \\
\hline & Diosmetin & Salvia tomentosa, Mentha spicata & Induction \\
\hline & Emodin & Cassia senna, Frangula alnus, Polygonum cuspidatum, Rhamnus frangula, Rheum and Rumex spp. & Induction \\
\hline & Oleanolic acid & Beta vulgaris, Lonicera nigra, Olea europaea & Inhibition \\
\hline & Quercetin & Quercus spp., Sophora japonica, Salix capraea, Polygonum nodosum & Induction \\
\hline \multirow[t]{7}{*}{ CYP2C9 } & Apigenin & $\begin{array}{l}\text { Tilia japonica, Linaria vulgaris, Cirsium arvense, Petroselium hortense, Apium graveolens, Matricaria } \\
\text { camomilla }\end{array}$ & Inhibition \\
\hline & Fisetin & Fragaria spp., Malus spp., Allium spp., Cucumis spp. & Inhibition \\
\hline & Kaempferol & Brassica oleracea, Fragaria spp., Solanum lycopersicum & Inhibition \\
\hline & Luteolin & Salvia officinalis, Reseda luteola, Brassica oleracea, Thymus vulgaris, Apium graveolens & Inhibition \\
\hline & Morin & Morus alba & Inhibition \\
\hline & Quercetin & Quercus spp., Sophora japonica, Salix capraea, Polygonum nodosum & Inhibition \\
\hline & Wogonin & Scutellaria spp. & Inhibition \\
\hline \multirow[t]{3}{*}{ CYP3A4 } & $\begin{array}{l}\text { Diallyl disulfide, } \\
\text { Diallyl sulfide }\end{array}$ & Allium sativum & Induction \\
\hline & Glycyrrhizine & Glycyrrhiza glabra & Induction \\
\hline & Hyperforin & Hypericum perforatum & Induction \\
\hline
\end{tabular}

Investigating the species-specific activity of drugmetabolizing CYP enzymes is of special importance in wild animals to gain some data concerning their susceptibility to certain drugs, carcinogens, toxicants of agricultural, and industrial origin (Boobis et al. 1990). Increased CYP activities may reflect elevated exposure to environmental or nutritional xenobiotics, but in the other hand, induced CYP enzymes provide faster drug metabolism, possibly contributing to safe game meat production being free of toxic residues.

In addition to the comparison of CYP enzymes in wild boar and domestic swine, wild boar fetuses were also included in the study, revealing that hepatic $\mathrm{CYP} 2 \mathrm{C} 9$ could be detected in all phases of fetal life, while CYP3A4 only during early pregnancy. However, the activity of fetal enzymes was much lower than in adults. Only very limited data is available concerning fetal drug metabolism in any species until now. It was found in human studies that the activity of CYP3A4 is approx. 40,000 times higher in the liver of adults than in fetuses, while CYP3A7, considered as a specific monooxygenase for fetal age, was 5500-times more active in fetuses compared to adults (Betts et al. 2015). In our study, the ratio of fetal to adult CYP3A4 activity was approx. 1:80, indicating that the difference between the xenobiotic exposure of fetuses and adults is much less in wild boars than in humans. CYP3A4 could be measured in wild boar fetuses only in the first phase of fetal life, which can mean that this enzyme, similarly to the human fetus-specific CYP3A7, is most active in the early phase of pregnancy. However, an increased load of a specific inducer cannot be excluded. The activity of CYP2C9 was moderate, but clearly measurable during the entire fetal life of wild boars, but it was not detectable in human fetuses, where further members of the CYP2C subfamily had an activity of around $5 \%$ of the adult values (Treluyer et al. 1997).

The effects of several factors on hepatic xenobiotic biotransformation were investigated in wild boars. We found that hepatic CYP1A2 was significantly increased in females compared to male boars. Similarly, it was also described in domestic Meishan pigs that the expression of hepatic CYP1A1 and CYP1A2 enzymes was significantly higher in females than in males (Kojima et al. 2010). In humans, CYP3A4 showed elevated activity in women than in men, but CYP1A2 was more active in males (Parkinson et al. 2004; Cotreau et al. 2005). The modulatory role of sex and sexual maturation is mostly suggested to be related to the intense steroid hormone synthesis (especially in males), requiring several hydroxylation steps catalyzed by CYP enzymes. In our study, this inducing effect of maturation could be found in wild boar sows regarding CYP3A4, which was more active in matured females than in juvenile ones. Notwithstanding that steroid hormone synthesis can strongly affect CYP activities, CYP2C9 was remarkably more active in female fetuses than in male ones during the last phase of pregnancy in wild boar, highlighting that some genetic factors may also exist behind the observed intersexual differences. 
It was already described that nutritional factors can also highly alter the function of CYP enzymes (Fink-Gremmels 2008; Mátis et al. 2013). According to our results, hepatic CYP1A2 of boars was significantly more active in the summer season than in winter, possibly related to the differing dietary conditions, resulting in the uptake of different plantderived compounds and altered nutrient supply. In the summer months, a lot more cereals and green plants are available than in winter time; hence, there are huge quantitative and qualitative changes in the diet. Further, more CYP influencer pesticides can be taken up in summer with the consumption of crops or green plants from agricultural fields, presumably provoking CYP induction. The modulatory action of bioactive plant compounds, such as carotenoids and flavonoids, was already described in sika deer (Darwish et al. 2010), underlining the role of nutritional composition in CYPdriven drug metabolism.

In contrast to the high hepatic enzyme activities, all assessed intestinal CYPs were under detection level in all gut sections of both wild boar and domestic swine. Previously, the activity of CYP1A2, CYP2H2, and CYP3A37 enzymes was successfully measured in duodenal mucosa of chickens with the same method by our research group (Kulcsár et al. 2017). In another study, the presence of the CYP1A1 enzyme and the CYP3A subfamily was confirmed with low expression levels in the intestinal mucosa of domestic swine, gradually decreasing along the intestines (Nielsen et al. 2017). Further, CYP1A2 could not be detected in the gut mucosa, but some members of the CYP2C and the CYP3A subfamilies were expressed in minor quantities in the small intestines of pigs (Puccinelli et al. 2011). Based on these data, intestinal CYP enzymes investigated in the present study seem not to play major role in xenobiotic biotransformation of suids (either wild or domesticated); however, the role of the gut in porcine drug metabolism cannot be neglected.

It is important to assess the presence of residues of environmental toxicants, such as pesticides or the long-persisting polychlorinated biphenyls (PCBs) in different tissues of exposed animals (Machala et al. 1998). Based on these investigations, some possible correlations might be highlighted between xenobiotic exposures and CYP enzyme activities; thus, CYPs may serve as important ecotoxicological markers. Due to their increased exposure to bioaccumulative agents, studies with marine species have already given some evidence for applying CYP enzymes as toxicological indicators. For instance, it was described in great cormorant (Phalacrocorax carbo), in gulls (Larus argentatus) and several marine fish species that one of the PCBs, 3,3',4,4'-tetrachloro-biphenyl (TCB) could particularly contribute to the inactivation of the CYP1A subfamily; thus, its tissue levels correlated with hepatic CYP1A activity (Schlezinger et al. 2000). Hence, monitoring CYP1A can provide some information about TCB exposition (Schlezinger et al. 2000). Among marine mammals, killer whales (Orcinus orca) showed especially intense PCB metabolism (Wolkers et al. 2007), mainly related to CYP2B and CYP3A subfamilies (Boon et al. 1992); therefore, investigating the aforementioned enzymes can deliver useful data on PCB contamination. The strong correlation of PCB exposure with hepatic CYP1A and CYP3A enzyme activities was also justified in ringed seal (Phoca hispida) (Wolkers et al. 1998).

Similarly to these sea-borne animals, connections between CYP-mediated drug metabolism and toxic contaminations were already studied in terrestrial animal species; however, only limited data are available. The correlation of hepatic concentrations of PCBs and 1,1-bis(4-chlorophenyl)-2,2,2trichloroethane (DDT) with certain CYP subfamilies was investigated by Machala et al. (1998) in cattle. The DDT significantly induced CYP3A2 expression in the liver of female rats as well, but no such elevations were found in males (SierraSantoyo et al. 2000). As DDT is highly persistent and has a great ability for bioaccumulation, this since decades already banned toxicant can still have important deteriorative effects in wild animal species, especially in omnivores, such as wild boar. Studying the presence of nowadays widely used pesticides (such as organophosphates, pyrethroids, glyphosate, etc) in the tissues of wild game species would be important to gain data on the possible correlations with hepatic CYP enzyme activities, confirming the role of xenobiotic metabolizing enzymes as species-specific indicators of environmental pollutant exposures. In the present study, residues of agricultural and industrial pollutants were not investigated in the organs of boars; thus, further trials are needed to analyze the correlations between tissue levels of toxic compounds and CYP activities. Notwithstanding that natural, dietary bioactive molecules of plant origin can be considered as the major CYP modulators in wild boar, further ecotoxicological studies would be also important to clarify the role of agricultural and industrial toxicants in affecting CYP enzymes.

Some regional differences in CYP enzyme levels may also exist due to altered dietary conditions and varied environmental contaminations of different areas. In our study, the two hunting grounds were both located in Western Hungary, close to each other, with similar geographical and agricultural conditions; thus, no differences were found between wild boars originated from these two different areas.

Studying the function and activity of CYP enzymes in different wild species can provide specific data about the toxicity of various compounds (Kurucz et al. 2018). Further, possible feed-drug or drug-drug interactions may be also highlighted (Csikó et al. 2014), delivering indispensable information for the safe application of feed additives and drugs in both freerange and farmed games. Nowadays, there is a continuously growing demand on safe, healthy wild meat production, which has to be free of any toxic and harmful residues. Studies on drug-metabolizing CYP enzymes in different wild 
species and their correlation with toxic exposures can drive practical benefits in food safety as well.

In conclusion, studying drug-metabolizing CYP enzymes in hunted wild animals can deliver useful information in basic science and advanced toxicology; further, CYPs can also considered as ecotoxicological markers and are being important from food hygiene point of view. This paper provided novel data on hepatic and intestinal xenobiotic biotransformation in wild boar, compared to domestic swine, describing several modulatory factors and addressing fetal drug metabolism as well. These results may open new insights to detoxification processes in wild boar, and can serve as good basis for further investigations.

Acknowledgments First of all, special thanks have to be granted to our hunter friends, Ádám Fazekas, Péter Fazekas, László Hirschler, Viktor Hirschler, Csaba Nagy and Krisztián Németh from the Széchenyi István (Sopronkövesd), and the Vadkert Hunting Association (Sárvár) for their kind help in wild boar samplings. The authors express many thanks to Károly Gorzsás (Keselyüs-Hús Kft., Szekszárd) for the possibility of sample collection from domestic pigs, to Dr. Ferenc Lakatos for his help in proper sample storing, and to Ferenc Mátis for kindly editing the figures. The professional assistance of Emma Kovács, Anna Kulcsár, and Dr. Patrícia Hatala in both the samplings and the laboratory analyses should be acknowledged. Finally, we want to express special thanks to Lucia Horváth, Erika Kurucz, and László Kurucz for their kind support.

Funding information Open access funding provided by University of Veterinary Medicine (ÁTE). The study was supported by the $9877-3$ / 2015/FEKUT and EFOP-3.6.3-VEKOP-16-2017-00005 grants of the Hungarian Ministry of Human Resources and by the NKFIH grant no. 124586 of the Hungarian National Research, Development and Innovation Office.

Data availability The datasets generated and analyzed during the current study are available from the corresponding author on reasonable request.

\section{Compliance with ethical standards}

Ethical approval All applicable international, national, and/or institutional guidelines for the care and use of animals were followed.

Conflict of interest The authors declare that they have no conflict of interest.

Open Access This article is licensed under a Creative Commons Attribution 4.0 International License, which permits use, sharing, adaptation, distribution and reproduction in any medium or format, as long as you give appropriate credit to the original author(s) and the source, provide a link to the Creative Commons licence, and indicate if changes were made. The images or other third party material in this article are included in the article's Creative Commons licence, unless indicated otherwise in a credit line to the material. If material is not included in the article's Creative Commons licence and your intended use is not permitted by statutory regulation or exceeds the permitted use, you will need to obtain permission directly from the copyright holder. To view a copy of this licence, visit http://creativecommons.org/licenses/by/4.0/.

\section{References}

Anzenbacher P, Anzenbacherová E (2001) Cytochromes P450 and metabolism of xenobiotics. Cell Mol Life Sci 58:737-747

Betts S, Björkhem-Bergman L, Rane A, Ekström L (2015) Expression of CYP3A4 and CYP3A7 in human foetal tissues and its correlation with nuclear receptors. Basic Clin Pharmacol 117:261-266

Boobis AR, Sesardic D, Murray BP et al (1990) Species variation in the response of the cytochrome P-450-dependent monooxygenase system to inducers and inhibitors. Xenobiotica 20:1139-1161

Boon JP, Van Arnhem E, Jansen S et al (1992) The toxicokinetics of PCBs in marine mammals with special reference to possible interactions of individual congeners with the cytochrome P450dependent monooxygenase system: an overview. In: Walker $\mathrm{CH}$, Livingstone DR (eds) Persistent pollutants in marine ecosystems. Pergamon Press, Oxford, pp 119-161

Buratti FM, D'Aniello A, Volpe MT, Meneguz A, Testai E (2005) Malathion bioactivation in the human liver: the contribution of different cytochrome P450 isoforms. Drug Metab Dispos 33:295-302

Csikó Gy, Nagy G, Mátis G et al (2014) Effects of dietary sodium butyrate on hepatic biotransformation and pharmacokinetics of erythromycin in chickens. J Vet Pharmacol Ther 37:406-412

Cotreau MM, Von Moltke LL, Greenblatt DJ (2005) The influence of age and sex on the clearance of cytochrome P450 3A substrates. Clin Pharmacokinet 44:33-60

Darwish WS, Ikenaka Y, Eldaly EA et al (2010) Cytochrome P450 1Adependent activities in deer, cattle and horses. J Vet Med Sci 72: $561-566$

Faragó S (2002) Vadászati állattan. Mezőgazda Lap- és Könyvkiadó, Budapest

Fink-Gremmels J (2008) Implications of hepatic cytochrome P450related biotransformation processes in veterinary sciences. Eur J Pharmacol 585:502-509

Harborne JB, Baxter H (1993) Phytochemical dictionary: a handbook of bioactive compounds from plants. Taylor \& Francis, Washington DC

Ishizuka M, Lee JJ, Masuda M, Akahori F, Kazusaka A, Fujita S (2006) CYP2D-related metabolism in animals of the Canoidea superfamily — species differences. Vet Res Commun 30:505-512

Kaur G, Jain AK, Singh S (2017) CYP/PON genetic variations as determinant of organophosphate pesticides toxicity. J Genet 96:187-201

Kojima M, Sekimoto M, Degawa M (2010) Androgen-mediated downregulation of CYP1A subfamily genes in the pig liver. J Endocrinol 207:203-211

Kulcsár A, Mátis G, Petrilla J, Neogrády Zs (2016) A bélnyálkahártya szerepe a xenobiotikumok biotranszformációjában, különös tekintettel a citokróm P450 enzimrendszerre. Irodalmi áttekintés. (The role of intestinal mucosa in the metabolism of xenobiotics with particular regard to cytochrome P450 enzyme system. Literature review) Magy Allatorvosok 138:243-250

Kulcsár A, Mátis G, Molnár A, Petrilla J, Wágner L, Fébel H, Husvéth F, Dublecz K, Neogrády Z (2017) Nutritional modulation of intestinal drug-metabolizing cytochrome $\mathrm{P} 450$ by butyrate of different origin in chicken. Res Vet Sci 113:25-32

Kurucz Á, Nagy Cs, Kulcsár A, Orbán K, Neogrády ZS, Mátis G (2018) Méregtelenítő folyamatok vizsgálata vadon élő állatfajokban. Irodalmi áttekintés. (Investigations of detoxifying processes in wild animal species. Literature review) Magy Allatorvosok 140:551-562

Lin JH, Masato C, Baillie TA (1999) Is the role of the small intestine in first-pass metabolism overemphasized? Pharmacol Rev 51:135-158

Machala M, Neca J, Drábek P et al (1998) Effects of chronic exposure to PCBs on cytochrome P450 systems and steroidogenesis in liver and testis of bulls (Bos taurus). Comp Biochem Phys A 120:65-70 
Machala M, Soucek P, Neca J, Ulrich R, Lamka J, Szotáková B, Skálová L (2003) Inter-species comparisons of hepatic cytochrome P450 enzyme levels in male ruminants. Arch Toxicol 77:555-560

Mátis G, Neogrády Zs, Csikó Gy, Kulcsár A, Kenéz Á, Huber K (2013) Effects of orally applied butyrate bolus on histone acetylation and cytochrome P450 enzyme activity in the liver of chicken - a randomized controlled trial. Nutr Metab 10:12

Nielsen SD, Bauhaus Y, Zamaratskaia G et al (2017) Constitutive expression and activity of cytochrome P450 in conventional pigs. Res Vet Sci 111:75-80

Paine MF, Shen DD, Kunze KL, Perkins JD, Marsh CL, McVicar J, Barr DM, Gillies BS, Thummel KE (1996) First-pass metabolism of midazolam by human intestine. Clin Pharmacol Ther 60:14-24

Parkinson A, Mudra DR, Johnson C, Dwyer A, Carroll KM (2004) The effects of gender, age, ethnicity, and liver cirrhosis on cytochrome P450 enzyme activity in human liver microsomes and inducibility in cultured human hepatocytes. Toxicol Appl Pharmacol 199:193-209

Puccinelli E, Gervasi PG, Longo V (2011) Xenobiotic metabolizing cytochrome P450 in pig, a promising animal model. Curr Drug Metab 12:507-525

Schlezinger JJ, Keller J, Verbrugge LA, Stegemann JJ (2000) 3,3',4,4'Tetrachlorobiphenyl oxidation in fish, bird and reptile species: relationship to cytochrome $\mathrm{P} 4501 \mathrm{~A}$ inactivation and reactive oxygen production. Comp Biochem Physiol C 125:273-286

Si D, Wang Y, Zhou YH, Guo Y, Wang J, Zhou H, Li ZS, Fawcett JP (2009) Mechanism of CYP2C9 inhibition by flavones and flavonols. Drug Metab Dispos 37:629-634

Sierra-Santoyo A, Hernández M, Albores A, Cebrián ME (2000) Sexdependent regulation of hepatic cytochrome P-450 by DDT. Toxicol Sci 54:81-87

Skálová L, Szotáková B, Machala M, Neca J, Soucek P, Havlasová J, Wsól V, Krídová L, Kvasnicková E, Lamka J (2001) Effect of ivermectin on activities of cytochrome P450 isoenzymes in mouflon (Ovis musimon) and fallow deer (Dama dama). Chem Biol Interact 137:155-167
Skupinska K, Misiewicz-Krzeminska I, Stypulkowski R, Lubelska K, Kaspryzycka-Guttman T (2009) Sulforaphane and its analogues inhibit CYP1A1 and CYP1A2 activity induced by benzo[a]pyrene. J Biochem Mol Toxicol 23:18-28

Thummel KE, O'Shea D, Paine MF et al (1996) Oral first-pass elimination of midazolam involves both gastrointestinal and hepatic CYP 3A4-mediated metabolism. Clin Pharmacol Ther 59:491-502

Treluyer JM, Gueter G, Cheron G, Sonnier M, Cresteil T (1997) Developmental expression of CYP2C and CYP2C-dependent activities in the human liver: in-vivo/in-vitro correlation and inducibility. Pharmacogenetics 7:441-452

Velík J, Baliharová V, Skálová L, Szotáková B, Wsól V, Lamka J (2005) Liver microsomal biotransformation of albendazole in deer, cattle, sheep and pig and some related wild breeds. J Vet Pharmacol Ther 28:377-384

Wolkers J, Burkow IC, Lydersen C, Dahle S, Monshouwer M, Witkamp RF (1998) Congener specific PCB and polychlorinated camphene (toxaphene) levels in Svalbard ringed seals (Phoca hispida) in relation to sex, age, condition and cytochrome P450 enzyme activity. Sci Total Environ 216:1-11

Wolkers H, Corkeron PJ, Van Parijs SM, Similä T, Van Bavel B (2007) Accumulation and transfer of contaminants in killer whales (Orcinus orca) from Norway: indications for contaminant metabolism. Environ Toxicol Chem 26:1582-1590

Wu CY, Benet LZ, Hebert MF, Gupta SK, Rowland M, Gomez DY, Wacher VJ (1995) Differentiation of absorption and first-pass gut metabolism in humans: studies with cyclosporin. Clin Pharmacol Ther 58:492-497

Zhou S, Gao Y, Jiang W, Huang M, Xu A, Paxton JW (2003) Interactions of herbs with cytochrome P450. Drug Metab Rev 35:35-98

Publisher's note Springer Nature remains neutral with regard to jurisdictional claims in published maps and institutional affiliations. 